\section{第 2 回日本産業技術大営候補の推䔍依頼について}

表彰対象

1. 産業発展に貢献度の高い産業設備の開発

2. 公害, 災害防止に効果の大きい設備の開発

3. 技術革新および流通革命に貢献度の高いシステム 開発

上記対象を满した，実際に工業化または活用されて成

果をあげた「研究開発グループ」を表彰するものであ る。

推薦締切り 昭和48年 1 月末まで

注）な括，大賞候補は表彰の前年 1 年間に開発された 技術成果の中から選らことになっています。

推萀宛先拈よび問合せ先

東京都千代田区九段北 1-8-10（元102）

日刊工業新聞社「日本産業技術大賞事務局」

\section{第19回西山記念技術講座開催について}

日時：昭和 48 年 1 月23日(火), 24 日(水)

会場：農協ホール Tel.03（279）0311

千代田区大手町 1 -8一-3 農協ビル9階

内容：溶接アーク下での治金反応 東北大学 小林卓郎 他 4 件

問い合せ先 日本鉄鋼協会編集課 Tel.03（279）6021

\section{第14回藤原賞受賞候補者推鳳依頼について}

(財)藤原科学財団では第14回藤原賞の推薦を募集して います。

推薦対象

1) 理学・工学・農学・医学の各部門

2）被推薦者はほかに賞を受けられた者であ，また前 に推薦された者でもよい。

3）被推薦者は原則として1人とし，共同研究者をあ げねばならぬ場合はその理由を明記する。

4）推薦は 1 件だとする。

5）推薦者は大学, 研究機関, 学会, 協会及び, 個人 （連名を含む）とする。

問い合せ先 （財)藤原科学財団 Tel. 03（561） 7736

俱 表

四松田，放射線による塗装のキュアリング，23，536（1972）

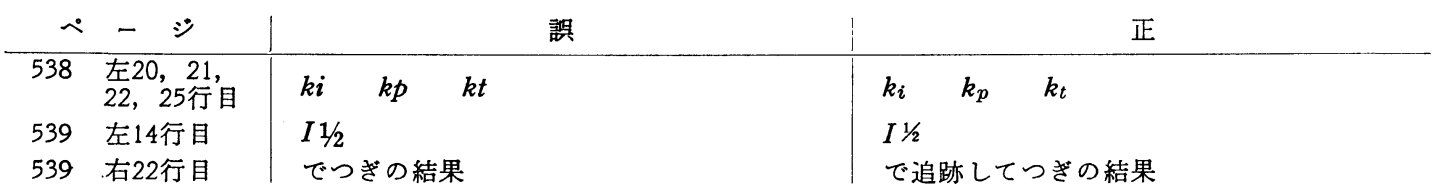

口高木, プリント配線基板の現状と今後の展望（その 2)，23，542（1972）

543 第 8 因説明 | (……てついて第 8 図参照)

I（……とつて第 7 因参照）

口田辺，釜崎，塩酸酸性塩化金酸浴に上る電析状金膜板晶の微細構造，23，572（1972）

572 英文 2 行目| under an transmission

" 英交 7 行目 in three dimensions, under a transmission in three dimension.

口小西，クロムメッキの浴電圧，23， 590 (1972)

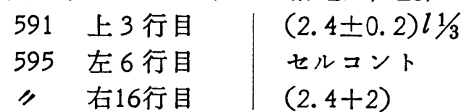

(2. $4 \pm 0.2) l 1 / 3$

セルコンスタント

(2. $4 \pm 2)$

西, クロムメッキの被覆力, 23， 596 (1972)

599 左 5 行目 | 陰極両極

陰陽両極

口畑野，佐藤，間接蒸着法による走査型電子顕微鏡用試料の作製とそのェッチング過程観察への適用, 23, 613(1972)

614 右 8 行目| 写真 1 の d

615 写真 2 説明 (a)と (b) は

口小西，クロムメッキの電流効率，23，632（1972）

632 左11行目|メッキからのクロムメッキ
写真 1 の b

(a)と (d)は 